We will try to publish authors' responses in the same edition with readers' comments. Time constraints might prevent this in some cases. The problem is compounded in a bimonthly journal where continuity of comment and redress are difficult to achieve. When the redress appears 2 months after the comment, 4 months will have passed since the original article was published. Therefore, we would suggest to our readers that their correspondence about published papers be submitted as soon as possible after the article appears.

\section{Screening For Dyslipidemia}

To the Editor: Expert panels appointed by the National Heart, Lung and Blood Institute recommend serum cholesterol measurements in all adults aged 20 years and older and cholesterol-lowering treatment for persons with elevated levels. ${ }^{1,2}$ After reviewing all major primary prevention trials, including the recent study from Scotland (the WOSCOPS ${ }^{3}$ ), we concluded that it is reasonable to limit screening for primary prevention and to treat hypercholesterolemia in such high-risk patients as those for whom randomized clinical trials demonstrated reduction in cardiovascular events. ${ }^{4} \mathrm{We}$ clearly indicate that our discussion is limited to primary prevention, and that extrapolation of results of secondary prevention trials to primary prevention and of results in high-risk middle-aged men to all adults is unwarranted.

In an invited editorial, Stein and $\mathrm{McBride}^{5}$ misread and misinterpret our analyses. In their zeal for population-based screening and aggressive treatment of asymptomatic persons, they lump primary prevention studies with those that are secondary. They imply that there are primary prevention trials other than the ones we reviewed; there are none. they imply that there are primary prevention trials in women and the elderly; there are none.

We are not alone in our call for randomized clinical trials in the aged and in women before applying the National Cholesterol Education Program recommendations ${ }^{1,2}$ to those groups. ${ }^{6-8}$ Until such studies are done, we are unwilling to extrapolate evidence from a single study in middle-aged men (WOSCOPS ${ }^{3}$ ) to all adults, and before embarking on population-based screening, we prefer to await additional evidence.

Jack Froom MD

Stony Brook, NY

Paul Froom MD

Tel Aviv, Israel

Mignon Benjamin MD

Brian Benjamin MD

Durham, NC

\section{References}

1. Report of the National Cholesterol Education Program Expert Panel on Detection, Evaluation and Treatment of High Blood Cholesterol in Adults. The Expert Panel. Arch Intern Med 1988; 148:36-69.

2. Second report of the Expert Panel on Detection, Evaluation, and Treatment of High Blood Cholesterol in Adults (adult treatment panel II). Bethesda, Md; National Cholesterol Education Program, National Institutes of Health, National Heart, Lung, and Blood Institute, 1993, (NIH publication no. 93-3095)

3. Shepherd J. Cobbe SM, Ford I, Isles CG, Lorimer AR, MacFarlane PW, et al. Prevention of coronary heart disease with pravastatin in men with hypercholesterolemia. West of Scotland Coronary Prevention Study Group. N Engl J Med 1995;333:1301-7.

4. Froom P. Froom P. Benjamin M, Benjamin BJ. Measurement and management of hyperlipidemia for the primary prevention of coronary heart disease. J Am Board Fam Pract 1998; 11:12-22.

5. Stein JH, McBride PE. Benefits of cholesterol screening and therapy for primary prevention of cardiovascular disease: a new paradigm. J Am Board Fam Pract 1998;11:7277.

6. Corti MC, Guralnik JM, Salive ME, Harris T. Ferrucci L, Glynn RJ, et al. Clarifying the direct relation between total cholesterol levels and death from coronary heart disease in older persons. Ann Intern Med 1997;126:753-60.

7. Anderson KM, Castelli WP, Levy D. Cholesterol and mortality: 30 years of follow-up from the Framingham study. JAMA 1987;257:2176-80.

8. Kronmal RA, Cain KC, Ye Z, Omenn GS. Total serum cholesterol levels and mortality risk as a function of age. A report based on the Framingham data. Arch Intern Med 1993; 153:1065-73. 